\title{
Rosalind Brown-Grant, Visualizing Justice in Burgundian Prose Romance: The "Roman de Gérard de Nevers" Illuminated by the Wavrin Master and Loyset Liédet
}

\section{Maria Colombo Timelli}

\section{(2) OpenEdition}

\section{Journals}

Édition électronique

URL : https://journals.openedition.org/studifrancesi/20927

DOI : $10.4000 /$ studifrancesi.20927

ISSN : 2421-5856

Éditeur

Rosenberg \& Sellier

Édition imprimée

Date de publication : 1 décembre 2019

Pagination : 553-554

ISSN : 0039-2944

Référence électronique

Maria Colombo Timelli, «Rosalind Brown-Grant, Visualizing Justice in Burgundian Prose Romance: The "Roman de Gérard de Nevers" Illuminated by the Wavrin Master and Loyset Liédet ", Studi Francesi [En ligne], 189 (LXIII | III) | 2019, mis en ligne le 01 mars 2020, consulté le 11 novembre 2021. URL : http:// journals.openedition.org/studifrancesi/20927 ; DOI : https://doi.org/10.4000/studifrancesi.20927

Ce document a été généré automatiquement le 11 novembre 2021.

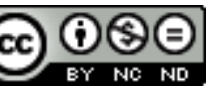

Studi Francesi è distribuita con Licenza Creative Commons Attribuzione - Non commerciale - Non opere derivate 4.0 Internazionale. 


\title{
Rosalind Brown-Grant, Visualizing Justice in Burgundian Prose Romance: The "Roman de Gérard de Nevers" Illuminated by the Wavrin Master and Loyset Liédet
}

\author{
Maria Colombo Timelli
}

\section{RÉFÉRENCE}

Rosalind Brown-Grant, Visualizing Justice in Burgundian Prose Romance: The "Roman de Gérard de Nevers" Illuminated by the Wavrin Master and Loyset Liédet, "Gesta" 57, 2018, pp. 69-93.

Composée en milieu bourguignon entre 1451 et 1464, l'adaptation en prose du Roman de la violette de Gerbert de Montreuil est conservée dans deux manuscrits enluminés ayant appartenu tous les deux aux collections des ducs de Bourgogne: le premier (Bruxelles, KBR, 9631), illustré par l'artiste connu comme le «Maître de Wavrin», fut sans doute offert à Philippe le Bon par Jean de Wavrin; le second (Paris, BnF, fr. 24378), commandité par le Duc lui-même, fut néanmoins enluminé après sa mort, par Loyset Liédet. La lecture comparative menée par R.B.-G. porte sur l'illustration de trois épisodes du roman, centrés sur l'administration de la justice par une autorité publique: le roi de France lors de la «gageure» à l'origine de l'intrigue et lors de la condamnation du traître Liziart, le duc de Metz lorsque l'héroïne est faussement accusée de meurtre. Dans les trois cas, la représentation adoptée par le Maître de Wavrin s'avère conforme aux procédures judiciaires de son temps, alors que Liédet privilégie de somptueuses scènes de cour. L'article est complété par deux Appendices: une liste des dix cycles iconographiques dont l'attribution au Maître de Wavrin est certaine, et la collation du 
contenu des enluminures de Gérard de Wavrin dans les deux manuscrits; on soulignera que le manuscrit de Paris en compte une de plus, le dernier chapitre étant divisé en deux parties, ce qui permet à Liédet d'illustrer la condamnation finale de Gondree, la «maistresse» qui a trahi la jeune protagoniste. 